\title{
FABRY DISEASE, FAMILY CASE REPORT
}

Lizeth Chaparro Del Portillo (SERVIÇO DE REUMATOLOGIA, HOSPITAL UNIVERSITÁRIO CLEMENTINO

FRAGA FILHO, RIO DE JANEIRO, RJ, Brasil), Júlia Yoneshigue Laranja de Oliveira (SERVIÇO DE REUMATOLOGIA, HOSPITAL UNIVERSITÁRIO CLEMENTINO FRAGA FILHO, RIO DE JANEIRO, RJ, Brasil), Hany Kelly Araujo Cruz (SERVIÇO DE REUMATOLOGIA, HOSPITAL UNIVERSITÁRIO CLEMENTINO FRAGA FILHO, RIO DE JANEIRO, RJ, Brasil), Bruno Bordalo Corrêa (SERVIÇO DE REUMATOLOGIA, HOSPITAL UNIVERSITÁRIO CLEMENTINO FRAGA FILHO, RIO DE JANEIRO, RJ, Brasil), Vivian Mabel Orsi Dorado (SERVIÇO DE REUMATOLOGIA, HOSPITAL UNIVERSITÁRIO CLEMENTINO FRAGA FILHO, RIO DE JANEIRO, RJ, Brasil), Hector Fabian Bernal Acevedo (SERVIÇO DE REUMATOLOGIA, HOSPITAL UNIVERSITÁRIO CLEMENTINO FRAGA FILHO, RIO DE JANEIRO, RJ, Brasil), Marcella Azevedo Borges Andrade (SERVIÇO DE REUMATOLOGIA, HOSPITAL UNIVERSITÁRIO CLEMENTINO FRAGA FILHO, RIO DE JANEIRO, RJ, Brasil), Federico Marcondes Santos (SERVIÇO DE REUMATOLOGIA, HOSPITAL UNIVERSITÁRIO CLEMENTINO FRAGA FILHO, RIO DE JANEIRO, RJ, Brasil), Blanca Elena Rios Gomes Bica (SERVIÇO DE REUMATOLOGIA, HOSPITAL UNIVERSITÁRIO CLEMENTINO FRAGA FILHO, RIO DE JANEIRO, RJ, Brasil)

\section{BACKGROUND}

Fabry disease (FD) is a rare hereditary metabolic disorder linked to the $X$ chromosome, caused by the partial or total deficiency of alpha-galactosidase A, related to mutations in the GLA gene (Xq21.3-q22). Its deficient activity may lead to the progressive accumulation of globotriaosylceramide and other glycosphingolipids in the lysosomes of various cell types throughout the body, causing severe complications of potentially fatal target organs.

Clinical manifestations of childhood or adolescence in the classical form include acroparasthesia, hypohidrosis, corneal opacities, stroke, cardiac anomalies, and renal disorders. In the variant form, the symptoms are usually mild and limited to heart or kidney. For this reason, patients often seek medical attention after the disease progresses. The diagnosis can be confirmed by the dosage of the alphagalactosidase enzyme and genetic analysis. Enzyme replacement therapy is the basis of treatment.

\section{CASE REPORT}

Familial cases of Fabry's disease, involving of 4 relatives. The first patient is a male, 24 years old, has started during childhood episodes of recurrent abdominal pain, pain in the hands and feet (acroparesthesia) and reduced sweating during exercise. Physical examination showed angiokeratomas in upper body and presence of cornea verticilata. Laboratory tests: normal renal function and presence of microalbuminuria. Alpha-galactosidase enzyme dosage $0.26 \mathrm{mmol} / \mathrm{mg}$ protein / hour (normal $>1.4$ ) and molecular analysis with homozygous mutation c.823delC (exon 6 in the alpha-galactosidase A gene), corroborating the diagnosis of FD at 14 years. After genetic and enzymatic research, her mother and sisters (from different parents) also received DF diagnosis. Mother had progression to chronic renal dialysis and cerebrovascular accident, while the sisters presented a clinic similar to the patient, abdominal pain, headache and acroparesthesia. All family members are receiving biweekly enzyme replacement, with control of the clinical condition

\section{CONCLUSION}

The triad composed of renal changes, angiokeratomas and limb pain in children or young males should always raise the suspicion of Fabry's disease, as in the cited patient. Because it's an X-linked pathology, most women are only carriers of the gene. In rare cases, as in the family case presented, female patients may be symptomatic. Often, there is a delay in diagnosis. Early enzyme replacement therapy may limit the severity of the manifestations, with improvement of clinical findings. 